American Journal of Environmental Sciences 1 (3): 213-220, 2005

ISSN 1553-345X

(c) 2005 Science Publications

\title{
Energy Flow in Agriculture: Bangladesh
}

\author{
${ }^{1}$ M.S. Alam, ${ }^{2}$ M.R. Alam and ${ }^{3}$ K.K. Islam \\ ${ }^{1}$ Institute of Energy Technology \\ Chittagong University of Engineeering and Technology, Chittagong 4349, Bangladesh \\ ${ }^{2}$ Department of Electrical and Electronic Engineering \\ Chittagong University of Engineeering and Technology, Chittagong 4349, Bangladesh \\ ${ }^{3}$ Department of Electrical and Electronic Engineering \\ Islamic University of Technology, Guzipur 0171, Bangladesh
}

\begin{abstract}
In this paper, a qualitative energy flow analysis in Bangladesh agriculture has been made for a period from 1980-81 to 2000-01 to evaluate the impact of energy input to produce output. Human \& animal muscle power and machinery energy for tillage operation, electricity and diesel energy for irrigation, fertilizer and pesticides energy for growth and protection are taken into account. Energy values are calculated by multiplying respective quantity by their respective energy equivalents with the use of relevant conversion factors. Energy flow studied based on some energy dependent indicators: energy input per ha, energy output per ha, energy output to input ratio, mechanization index, energy input to generate per unit GDP output as well as per unit output in energy term and solar energy conversion efficiency. During the study period, energy input and output to Bangladesh agriculture were increased from 6.4 to $17.32 \mathrm{GJ} \mathrm{ha}^{-1}$ and 72.22 to $130.05 \mathrm{GJ} \mathrm{ha}^{-1}$, respectively. It is found that energetic efficiency (energy output to input ratio) was declined from $11.28 \%$ to $8.1 \%$, which indicates that the energy input increased faster than energy output. It is expected that sustainable energy flow in Bangladesh agriculture can be ascertained by this study.
\end{abstract}

Key words: Bangladesh, Energy flow, agricultural growth, economic development

\section{INTRODUCTION}

In LDCs like Bangladesh, agricultural growth is essential for fostering the economic development and feeding growing population. The big challenge of agriculture in the coming years is not only to satisfy the growing effective demand of food but also to satisfy the increasing demand of cooking fuel as well as to meet the cattle feed.

The relation between agriculture and energy is very close. Agriculture itself is an energy user and energy supplier in the form of bio-energy. At present productivity and profitability of agriculture depend on energy consumption. For the growth and development, energy demand in agriculture can be divided into direct and indirect energy. Energy inputs are sun and support energy. Support direct energy is required for land preparation, irrigation, harvest, post harvest processing, transportation of agricultural inputs and outputs. Support indirect energy is used in the form of fertilizer and pesticides. Energy use depends on mechanization level, the quantity of active agricultural worker and cultivable land ${ }^{[1]}$.

Agriculture is the means of livelihood for the majority of the people and main source of GDP share. In 2000-01, the agricultural GDP share of the total GDP of Bangladesh at the current price was $30 \%^{[2]}$. Bangladesh have a limited land for agricultural development. It was found that the cultivated land was 8.56 million ha in 1980-81 and it became 8.08 million ha in 2000-01 with a decreasing rate of $0.28 \%{ }^{[3]}$. The cultivable land coverage are as follows: Rice $75 \%$, Pulses $4.64 \%$, Wheat $3.92 \%$, Oil seeds $3.77 \%$, Jute $3.7 \%$, Sugarcane $1.23 \%$, Potato $1.11 \%$, Fruits $0.84 \%$ and Vegetables $1.39 \%{ }^{[4]}$.

For tillage operation, use of power tiller increased significantly. Use of fertilizer and pesticides increased from 0.87 to 3.3 and from 0.002 to 0.01 millions MT respectively and irrigated area increased from $19.5 \%$ to $55 \%$ of the cultivated land ${ }^{[2]}$ during the study period.

Despite of various shortcomings in the land utilization system, over the last two decades Bangladesh has greatly increased its food grains from 13 millions MT in 1980-81 to 24 millions MT in 2000$01^{[5]}$. From 1980 to 1998 Bangladesh was a food deficit country and from 1999 achieved self-sufficiency in food as well as in fodder and rural domestic cooking fuel production. Rice takes the main share i.e. $95 \%$ of the total production and followed by wheat with a share of $4.5 \%{ }^{[5]}$.

As a result of development, energy consumption in Bangladesh agriculture has greatly increased in recent

Corresponding Author: M.S. Alam, Institute of Energy Technology, Chittagong University of Engineeering and Technology, Chittagong 4349, Bangladesh, Tel: +88031714952 , Fax: +88031714910 
years. If the increase of input energy continues, the total output of agriculture will be increased; where the total cultivated land will be reduced slowly. Under these circumstances, an energy flow analysis provides planners and policy makers an opportunity to evaluate the performance of agricultural system on energy use.

The objectives of the study to evaluate the performance of Bangladeshi agricultural system on energy use are:

* To assess the role of energy in production

* To evaluate the agricultural contribution to generate GDP and

* To assess the energetic efficiency(energy ratio) as well as the solar conversion efficiency with respect to energy input.

Singh $^{[6]}$ stated that growth of crop production depends on the three sources: arable land expansion, increase in cropping intensity and yield growth. Okurut et al. ${ }^{[7]}$ reported that besides land, farm power is the second most important input to agricultural production. Warkentin $^{[8]}$ stated that water use efficiency is highly concern of crop management. Barton ${ }^{[9]}$ reported that farm power determines the scale and intensity of farm operation. Sarker ${ }^{[10]}$ reported that adoption of power tillers for tilling has brought some significant changes on overall production and sustainability of small farm systems. Borlaugh et al. ${ }^{[11]}$ stated that crop production environment including the generation and transfer of appropriate technology must be improved to increase the fertilizer use efficiency to meet the challenge of feeding increased population. Alam et al. ${ }^{[12]}$ illustrated a system dynamics model for analyzing different input energy use in rural farming system. Alam ${ }^{[13]}$ developed a simulation model of input energy structure of Bangladesh agriculture to evaluate the effectiveness of various agricultural energy inputs. In this context, an analysis has been done to evaluate the performance of energy flow in Bangladeshi agriculture.

\section{METHOD AND MATERIALS}

The energetic efficiency of the agricultural system has been evaluated by the energy ratio between output and input for the period 1980-2001. Human and animal labor, machinery, electricity, diesel oil, fertilizer, pesticides and seed amounts and output yield values of cereal crops have been used to estimate the energy ratio. Energy equivalents shown in Table 1 were used for estimation.

For human muscle power, the economically active agricultural population is considered above 15 years $^{[2]}$. Only cattle are used as draft animal in agriculture. For estimation of gross energy input to agriculture, working days of agricultural worker is considered as 207 days per year ${ }^{[14]}$, an average $8 \mathrm{hr}$. work per day and the average working hours of an animal in agriculture are considered $360 \mathrm{hr}$. per year ${ }^{[1]}$. Since, there is no data available for diesel consumption of machinery used in agriculture, the total diesel energy input to agriculture was calculated from the diesel consumed by power tillers. Therefore, it was assumed that a 10-hp power tiller $^{[15]}$ consumes $1.75 \mathrm{~L}$ diesel per hr. with an $80 \%$ loading capacity and its average used on the field is 720 $\mathrm{hr}^{[1]}$ per year. Data on electricity and diesel used in irrigation were collected from field investigation.

Chemical energy input data on individual fertilizer materials (nitrogen, phosphate and potash) and pesticides were used from available source ${ }^{[3]}$ in estimation. The total energy input from fertilizer was calculated by summing the energy amounts of individual fertilizer nutrient. Amount of pesticide was also converted to energy equivalent. Seed is considered a form of energy input to agriculture. $2.8 \%$ of the product was taken as seed ${ }^{[5]}$. In this study rice, wheat and their residues were considered as output in energy estimation.

Energy output from the product was calculated by multiplying the amount of production and its corresponding energy equivalence. Estimation of byproduct rice husk of the product is taken, as $33.33 \%$ of the grain ${ }^{[5]}$ and straw is to be equal to the weight of the grain $^{[16]}$. Energy output from the by-product was estimated by multiplying the amount of by-product and its corresponding energy equivalent.

Evaluation of the performance of agricultural production system has been made with a set of evaluating indicators/parameters. The parameters are food surplus index (FSI), fodder surplus index (SSI), cooking fuel surplus index (CSI), mechanization index (MEI), Energy input to produce per unit energy output (EIO), energy input to generate per unit GDP output, energetic efficiency of the system (EEA) and solar conversion efficiency (SCE). Those are represented by the following equations:

$\mathrm{FSI}=[(\mathrm{FDA}-\mathrm{FDD}) / \mathrm{FDD}] \times 100 \%$

$\mathrm{SSI}=[(\mathrm{STA}-\mathrm{STD}) / \mathrm{STD}] \times 100 \%$

$\mathrm{CSI}=[(\mathrm{CFA}-\mathrm{CFD}) / \mathrm{CFD}] \times 100 \%$

$\mathrm{MEI}=[\mathrm{TCI} / \mathrm{TIE}] \times 100 \%$

$\mathrm{EIO}=[\mathrm{TIE} / \mathrm{TOE}] \mathrm{MJ} / \mathrm{GJ}$

$\mathrm{EIG}=[\mathrm{TIE} / \mathrm{GDP}] \mathrm{MJ} /$ million \$

$\mathrm{EEA}=[\mathrm{TOE} / \mathrm{TIE}] \times 100 \%$

$\mathrm{SCE}=[\mathrm{TOE} / \mathrm{SEI}] \times 100 \%$

Food demand is estimated by multiplying the total population with food co-efficient. Food co-efficient per person per day is taken as 16 -ounces ${ }^{[4]}$. 
Table 1: Energy co-efficient for agricultural energy sources

\begin{tabular}{|c|c|c|}
\hline SL No & Description & Energy Co-efficient \\
\hline 1. & Human Muscle Power ${ }^{[15]}$ & $0.1 \mathrm{hp} /$ labour \\
\hline 2. & Animal Draft Power ${ }^{[15]}$ & $0.25 \mathrm{hp} / \mathrm{head}$ \\
\hline 3. & Power Tiller $^{[15]}$ & $10 \mathrm{hp} \mathrm{unit}^{-1}$ \\
\hline 4. & Energy in Commercial fertilizer - Nitrogen ${ }^{[16]}$ & $60.6 \mathrm{MJ} \mathrm{kg}^{-1}$ \\
\hline 5 & Energy in Commercial fertilizer - Phosphorus ${ }^{[16]}$ & $11.1 \mathrm{MJ} \mathrm{kg}^{-1}$ \\
\hline 6. & Energy in Commercial fertilizer - Potassium ${ }^{[16]}$ & $06.7 \mathrm{MJ} \mathrm{kg}^{-1}$ \\
\hline 7. & Diesel $^{[1]}$ & $56.4 \mathrm{MJ} \mathrm{L}^{-1}$ \\
\hline 8. & Electricity $^{[1]}$ & $11.93 \mathrm{MJ} \mathrm{kWh}^{-1}$ \\
\hline 9. & Energy for Commercial Pesticides ${ }^{[18]}$ & $0.101 \mathrm{MJ} \mathrm{kg}^{-1}$ \\
\hline 10. & Energy in Rice ${ }^{[13]}$ & $14.7 \mathrm{MJ} \mathrm{kg}^{-1}$ \\
\hline 11. & Average Solar energy incident ${ }^{17]}$ & $65.13 \times 10^{3} \mathrm{GJ} \mathrm{ha}^{-1}$ \\
\hline 12 & Energy in Rice Husk ${ }^{16]}$ & $13.8 \mathrm{MJ} \mathrm{kg}^{-1}$ \\
\hline 13 & Energy in Rice Straw ${ }^{[16]}$ & $19.7 \mathrm{MJ} \mathrm{kg}^{-1}$ \\
\hline 14. & Energy in Seed ${ }^{[16]}$ & $14.7 \mathrm{MJ} \mathrm{kg}^{-1}$ \\
\hline
\end{tabular}

Table 2: Physical power available and energy input to Bangladeshi agriculture

\begin{tabular}{|c|c|c|c|c|c|}
\hline Items & $1980-81$ & $1985-86$ & 1990-91 & $1995-96$ & 2000-01 \\
\hline Active human labor $\left(\times 10^{6}\right)$ & 30.4 & 32.8 & 35.0 & 37.1 & 38.7 \\
\hline Total human power $\left(\times 10^{6} \mathrm{hp}\right)$ & 3.04 & 3.28 & 3.50 & 3.70 & 3.87 \\
\hline Energy from human $\left(\times 10^{15} \mathrm{~J}\right)$ & 13.51 & 14.57 & 15.58 & 16.47 & 17.22 \\
\hline Draft cattle $\left(\times 10^{6}\right)$ & 11.60 & 11.60 & 11.60 & 11.00 & 9.70 \\
\hline Total draft power $\left(\times 10^{6} \mathrm{hp}\right)$ & 2.93 & 2.93 & 2.93 & 2.75 & 2.43 \\
\hline Energy from cattle $\left(\times 10^{15} \mathrm{~J}\right)$ & 2.83 & 2.83 & 2.83 & 2.66 & 2.35 \\
\hline Power Tiller $\left(\times 10^{6}\right)$ & 0.03 & 0.06 & 0.12 & 0.18 & 0.30 \\
\hline Total Machinery power $\left(\times 10^{6} \mathrm{hp}\right)$ & 0.30 & 0.60 & 1.20 & 1.80 & 3.00 \\
\hline Energy from Machinery $\left(\times 10^{15} \mathrm{~J}\right)$ & 2.13 & 4.30 & 8.50 & 12.80 & 21.30 \\
\hline Total physical power $\left(\times 10^{6} \mathrm{hp}\right)$ & 6.27 & 6.81 & 7.63 & 8.25 & 9.30 \\
\hline Energy for Irrigation $\left(\times 10^{15} \mathrm{~J}\right)$ & 9.27 & 11.34 & 16.06 & 17.13 & 17.81 \\
\hline Total physical energy input $\left(\times 10^{15} \mathrm{~J}\right)$ & 27.74 & 33.05 & 42.97 & 49.06 & 58.68 \\
\hline
\end{tabular}

Table 3: Estimated chemical energy input $\left(\times 10^{15} \mathrm{~J}\right)$ to Bangladeshi agriculture

\begin{tabular}{|c|c|c|c|c|c|}
\hline Items & $1980-81$ & $1985-86$ & 1990-91 & $1995-96$ & 2000-01 \\
\hline $\mathrm{N}_{2}$ used $\left(\times 10^{6}\right.$ ton $)$ & 0.265 & 0.365 & 0.610 & 0.943 & 1.060 \\
\hline $\mathrm{N}_{2}$ used per ha $\left(\mathrm{kg} \mathrm{ha}^{-1}\right)$ & 31.0 & 42.0 & 75.0 & 121.0 & 131.0 \\
\hline $\mathrm{N}_{2}$ recommended dose $\left(\mathrm{kg} \mathrm{ha}^{-1}\right)$ & 50.0 & 50.0 & 50.0 & 50.0 & 50.0 \\
\hline $\mathrm{P}_{2} \mathrm{O}_{5}$ used $\left(\times 10^{6}\right.$ ton $)$ & 0.118 & 0.137 & 0.239 & 0.147 & 0.247 \\
\hline $\mathrm{P}_{2} \mathrm{O}_{5}$ used per ha $\left(\mathrm{kg} \mathrm{ha}^{-1}\right)$ & 14.0 & 16.0 & 29.0 & 19.0 & 31.0 \\
\hline $\mathrm{P}_{2} \mathrm{O}_{5}$ recommended dose $\left(\mathrm{kg} \mathrm{ha}^{-1}\right)$ & 40.0 & 40.0 & 40.0 & 40.0 & 40.0 \\
\hline $\mathrm{K}_{2} \mathrm{O}$ used $\left(\times 10^{6}\right.$ ton $)$ & 0.027 & 0.036 & 0.090 & 0.093 & 0.140 \\
\hline $\mathrm{K}_{2} \mathrm{O}$ used per ha $\left(\mathrm{kg} \mathrm{ha}^{-1}\right)$ & 3.10 & 4.00 & 11.00 & 12.00 & 17.00 \\
\hline $\mathrm{K}_{2} \mathrm{O}$ recommended dose $\left(\mathrm{kg} \mathrm{ha}^{-1}\right)$ & 20.00 & 20.00 & 20.00 & 20.00 & 20.00 \\
\hline $\mathrm{N}_{2}: \mathrm{P}_{2} \mathrm{O}_{5}: \mathrm{K}_{2} \mathrm{O}$ used & 10:4.5:1 & 10:4:1 & $7: 2.5: 1$ & $10: 1.5: 1$ & 7.7:1.8:1 \\
\hline $\mathrm{N}_{2}: \mathrm{P}_{2} \mathrm{O}_{5}: \mathrm{K}_{2} \mathrm{O}$ recommended & $2.5: 2: 1$ & $2.5: 2: 1$ & $2.5: 2: 1$ & $2.5: 2: 1$ & $2.5: 2: 1$ \\
\hline Energy from fertilizer & 17.73 & 24.14 & 40.00 & 60.00 & 64.00 \\
\hline Pesticides $\left(\times 10^{3}\right.$ tons $)$ & 2.30 & 3.70 & 7.20 & 11.30 & 15.40 \\
\hline Energy from pesticides $\left(\times 10^{15} \mathrm{~J}\right)$ & 0.23 & 0.37 & 0.73 & 1.15 & 1.56 \\
\hline Total chemical energy input $\left(\times 10^{15} \mathrm{~J}\right)$ & 17.96 & 24.51 & 40.73 & 61.15 & 65.56 \\
\hline
\end{tabular}

Annual straw demand was estimated multiplying fodder co-efficient for cattle by total cattle population. Cooking fuel demand was estimated multiplying cooking fuel co-efficient by rural people. Fodder coefficient and Cooking fuel co-efficient were taken as

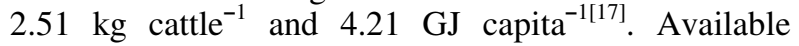
fodder was taken as $66 \%$ of the straw available. Cooking fuel available is equal to the summation of wheat straw, rice husk and non-fodder straw. Annual non-fodder straw was estimated subtracting the fodder straw from the straw available with a multiplying factor $0.6^{[17]}$.

Physical power sources: The physical power sources of Bangladesh agriculture were investigated and presented in Table 2. Inputs such as human labor, animal power and machinery used in agriculture were expressed as physical power source. According to the Population Censuses in 1980-81, 1990-91 and 2000-01, the annual population growth rate was $2.5,2.48$ and $2.12 \%$ respectively. But, it was found that total population was involved in agriculture was decreased from $73 \%$ in $1980-81$ to $55 \%$ in $2001^{[2]}$. The Table 2 shows the available active agricultural labor growth rate was $1.5 \%$ in $1980-81$ and was $0.86 \%$ in 2000-01. The use of animal's power in agricultural system decreased significantly in the last decade. So the average animal power dropped from 2.93 to 2.43 million hp during the study period. 
During the last decade, the average animal power dropped $17.06 \%$. In this period, the number of power tillers rose from 0.03 million to 0.3 million. The average power available from power tillers increased from 0.30 million hp to 3.00 million hp during the study period. It is found that the physical power rose from 6.27 million hp in $1980-81$ to 9.30 million hp in $2000-$ 01. It shows that the physical power obtained from power tiller increased ten-fold during the study period.

Physical energy as an input to agriculture consists of human muscle power, draft power from animal and machinery, electricity and diesel energy consumption for irrigation. The physical energy input was estimated to be $27.74 \times 10^{15} \mathrm{~J}$ in $1980-81$ and it reached at 58.68 $\times 10^{15} \mathrm{~J}$ in $2000-01$. This shows that the physical energy input used in agricultural system increased by $111 \%$ in the last two decades.

Chemical energy input: Chemical energy is embedded energy in fertilizer and pesticides. In calculation of chemical fertilizer energy input in agricultural system, $\mathrm{N}_{2}, \mathrm{P}_{2} \mathrm{O}_{5}$ and $\mathrm{K}_{2} \mathrm{O}$ were taken into account and the estimated values with its recommended dose were presented in Table 3 and Table 3.The energetic ratio of $\mathrm{N}_{2}, \mathrm{P}_{2} \mathrm{O}_{5}$ and $\mathrm{K}_{2} \mathrm{O}$ were also presented with.

Total fertilizer energy input was calculated as $17.73 \times 10^{15} \mathrm{~J}$ in $1980-81$ and it reached $64 \times 10^{15} \mathrm{~J}$ in 2000-01. This shows that the fertilizer energy input increased by $261 \%$ in the last two decades. The energetic ratio of the fertilizer components was 10:4.5:1 in $1980-81$ and it was $7: 1.8: 1$ in $2000-01$, where the recommended ratio is $2.5: 2: 1$. The amount of energy input from pesticides in comparison to fertilizer is insignificant. But its contribution to produce output as well as to maintain environment is quite significant. As can be seen from the Table, the total pesticides energy input was calculated as $0.23 \times 10^{15} \mathrm{~J}$ in $1980-81$ and it reached $1.56 \times 10^{15} \mathrm{~J}$ in $2000-01$. This shows that the pesticides energy input increased 6.8 -fold during the study period.

Biochemical energy input: Biochemical energy is the amount of energy stored in the seed. The calculated energy input from seed during the study period was presented in row 6 of the Table 4. As can be seen from the row the total seed energy input was calculated as $9.1 \times 10^{15} \mathrm{~J}$ in $1980-81$ and it reached $15.6 \times 10^{15} \mathrm{~J}$ in 2000-01. This shows that the seed energy input increased by $71.42 \%$ during the study period.

Total energy input and output: Table 4 represents the total energy input and output of agricultural production system. It is seen that the total input energy increased by $159 \%$ from $1980-81$ to $2000-01$.Therefore, the input energy increased from 6.40GJ ha ${ }^{-1}$ in $1980-81$ to 17.32 GJ $\mathrm{ha}^{-1}$ in 2000-01. It was found that the total food production rose from 15.2 million ton in 1980-81 to
25.8 million ton in 2000-01. It was also found that the energy produced from total output including by-product rose from $618.2 \times 10^{15} \mathrm{~J}$ in $1980-81$ to $1050.8 \times 10^{15} \mathrm{~J}$ in 2000-01 and energy produced from only by-product rose from $394.7 \times 10^{15} \mathrm{~J}$ in $1980-81$ to $672.5 \times 10^{15} \mathrm{~J}$ in 2000-01.

\section{RESULT AND DISCUSSION}

The power and energy input from various sources and energy output are calculated in per hectare basis. The performance evaluating indicators/parameters are illustrated in Table 5. The Table shows that the cultivated area is reducing rather than expanding. Output product and by-product depend on only level of energy input. It is found that the muscle power input didn't increased since last two decades. However, the physical power input significantly increased during the same period due to only mechanical energy input for tillage operation. It is seen that the contribution of mechanical power was $11.2 \%$ of the total physical power in 1990-81; on the other hand, it was $51.8 \%$ in 2000-01 (Table 2).

Rapid growth of mechanical power input has made a significant contribution to the total draft power available. Early 80's, it is found that the draft power including animal power and mechanical power available $\left(0.28 \mathrm{~kW} \mathrm{ha}^{-1}\right)$ was less than that of draft power demand $\left(0.373 \mathrm{~kW} \mathrm{ha}^{-1}\right)^{[19]}$. At the end of the last decade the draft power available was $0.49 \mathrm{~kW} \mathrm{ha}^{-1}$, which has a significant contribution to produce output product and by-product. In the last decade, the government liberalized the policy to import the agricultural machinery ${ }^{[20]}$. As a result, a large number of power tillers were imported and sufficient draft power is available. Therefore, physical power input level improved significantly.

It was observed at the beginning of the study period that the share of commercial energy in total physical energy input was $41 \%$, where the share of muscle power obtained from human and animal was $59 \%$. At the end of the study period, the share of that commercial energy consumption reached at $66 \%$. However, there was increase electricity and diesel oil consumption and it made a significant contribution to improve the input energy level to produce increased output.

It was found from Table 3, fertilizer energy input is increasing rapidly in comparison to physical energy input. The fertilizer energy input increased from 17.73 $\times 10^{15} \mathrm{~J}$ to $64.69 \times 10^{15} \mathrm{~J}$ during the same period. However, the highest growth rate of fertilizer use was found in 1990-91 and lowest growth rate in 2000-01. In addition, energy input from pesticides and seed increased uniformly over the study period.

Energy inputs from physical power, electricity, diesel oil, fertilizer and pesticides and seed have a 
Am. J. Environ. Sci., 1 (3): 213-220, 2005

Table 4: Estimated energy input and output to Bangladeshi agriculture

\begin{tabular}{|c|c|c|c|c|c|}
\hline Energy type & $1980-81$ & $1985-86$ & 1990-91 & $1995-96$ & 2000-01 \\
\hline \multicolumn{6}{|l|}{ Inputs: $\left(\times 10^{15} \mathrm{~J}\right)$} \\
\hline Human \& animal power & 16.34 & 17.4 & 18.41 & 19.40 & 19.13 \\
\hline Machine power & 2.13 & 4.28 & 8.50 & 12.80 & 21.30 \\
\hline Energy for Irrigation & 9.27 & 11.35 & 16.06 & 17.14 & 17.81 \\
\hline Fertilizer & 17.73 & 24.14 & 40.00 & 60.00 & 64.69 \\
\hline Pesticide & 0.23 & 0.37 & 0.73 & 1.15 & 1.56 \\
\hline Seed & 9.10 & 10.10 & 12.20 & 13.70 & 15.60 \\
\hline Total input energy & 54.80 & 67.66 & 96.52 & 123.79 & 141.81 \\
\hline \multicolumn{6}{|l|}{ Outputs: } \\
\hline Rice $\left(\times 10^{6}\right.$ tons $)$ & 14.1 & 15.4 & 18.1 & 18.8 & 24.1 \\
\hline Energy from Rice $\left(\times 10^{15} \mathrm{~J}\right)$ & 207.30 & 226.40 & 266.10 & 276.40 & 354.40 \\
\hline Wheat $\left(\left(\times 10^{6}\right.\right.$ tons $)$ & 1.1 & 1.0 & 1.0 & 1.4 & 1.7 \\
\hline Energy from Wheat $\left(\times 10^{15} \mathrm{~J}\right)$ & 16.20 & 14.7 & 14.7 & 20.6 & 25.0 \\
\hline Rice husk $\left(\times 10^{15} \mathrm{~J}\right)$ & 95.20 & 104.3 & 122.8 & 126.9 & 163.2 \\
\hline Rice straw $\left(\times 10^{15} \mathbf{J}\right)$ & 277.80 & 303.40 & 356.60 & 370.40 & 474.80 \\
\hline Wheat straw $\left(\times 10^{15} \mathrm{~J}\right)$ & 21.70 & 19.70 & 19.70 & 27.60 & 33.50 \\
\hline Total food $\left(\times 10^{6}\right.$ tons $)$ & 15.2 & 16.4 & 19.1 & 20.2 & 25.8 \\
\hline Total food energy $\left(\times 10^{15} \mathrm{~J}\right)$ & 223.50 & 241.10 & 280.80 & 297.00 & 379.40 \\
\hline Total agricultural. Residue energy $\left(\times 10^{15} \mathrm{~J}\right)$ & 394.70 & 421.40 & 498.70 & 524.90 & 672.50 \\
\hline Total output energy $\left(\times 10^{15} \mathrm{~J}\right)$ & 618.20 & 668.50 & 779.50 & 821.90 & 1050.80 \\
\hline Parameters & $1980-81$ & $1985-86$ & $1990-91$ & $1995-96$ & $2000-01$ \\
\hline Available human power $\left(\mathrm{kW} \mathrm{ha}^{-1}\right)$ & 0.265 & 0.279 & 0.320 & 0.354 & 0.357 \\
\hline Available animal power $\left(\mathrm{kW} \mathrm{ha}^{-1}\right)$ & 0.255 & 0.249 & 0.267 & 0.263 & 0.224 \\
\hline Available Machine power $\left(\mathrm{kW} \mathrm{ha}^{-1}\right)$ & 0.026 & 0.051 & 0.11 & 0.172 & 0.277 \\
\hline Fertilizer energy input $\left(\mathrm{GJ} \mathrm{ha}^{-1}\right)$ & 2.07 & 2.76 & 4.89 & 7.69 & 8.01 \\
\hline Pesticides energy input $\left(\mathrm{GJ} \mathrm{ha}^{-1}\right)$ & 0.03 & 0.04 & 0.09 & 0.15 & 0.20 \\
\hline Chemical energy input $\left(\mathrm{GJ} \mathrm{ha}^{-1}\right)$ & 2.10 & 2.80 & 4.98 & 7.84 & 8.21 \\
\hline Irrigated energy input $\left(\mathrm{GJ} \mathrm{ha}^{-1}\right)$ & 1.08 & 1.30 & 1.96 & 2.20 & 2.20 \\
\hline Machinery energy input $\left(\mathrm{GJ} \mathrm{ha}^{-1}\right)$ & 0.25 & 0.49 & 1.07 & 1.68 & 2.65 \\
\hline Seed energy input $\left(\mathrm{GJ} \mathrm{ha}^{-1}\right)$ & 1.06 & 1.15 & 1.49 & 1.76 & 1.93 \\
\hline Total energy input $\left(\mathrm{GJ} \mathrm{ha}^{-1}\right)$ & 6.40 & 7.74 & 11.81 & 15.87 & 17.43 \\
\hline Food production $\left(\right.$ Ton $\left.\mathrm{ha}^{-1}\right)$ & 1.77 & 1.87 & 2.33 & 2.69 & 3.19 \\
\hline Output food energy $\left(\mathrm{GJ} \mathrm{ha}^{-1}\right)$ & 26.22 & 27.55 & 34.37 & 38.08 & 46.96 \\
\hline Fodder surplus index $(\%)$ & -30.20 & -24.77 & -11.51 & -8.73 & +1.64 \\
\hline Cooking fuel surplus index (\%) & -42.30 & -42.00 & -36.50 & -36.70 & -9.05 \\
\hline Food surplus index $(\%)$ & -3.79 & -3.70 & -0.71 & -7.78 & 6.15 \\
\hline Total output $\left(\mathrm{GJ} \mathrm{ha}^{-1}\right)$ & 72.22 & 76.47 & 95.46 & 105.37 & 130.18 \\
\hline Energetic efficiency (\%) & 11.28 & 9.88 & 8.08 & 7.78 & 8.10 \\
\hline Mechanization index $(\%)$ & 70.18 & 74.28 & 80.93 & 84.56 & 86.10 \\
\hline GDP from agriculture $\left(\times 10^{6} \$\right)$ & 6267 & 7951 & 9146 & 10809 & 11186 \\
\hline Solar conversion efficiency (\%) & 0.11 & 0.12 & 0.15 & 0.16 & 0.21 \\
\hline
\end{tabular}

linear increase during the study period (Table 4). As can be seen from the Table 4, there was a 3.75 fold increase in terms of fertilizer energy input for $\mathrm{N}_{2}, 2.1$ fold, for $\mathrm{P}_{2} \mathrm{O}_{5}$ and 5.18-fold for $\mathrm{K}_{2} \mathrm{O}$. The Table also shows that $\mathrm{N}_{2}$ used per ha increased from 31.0 to 131 $\mathrm{kg}$, where recommended dose $50 \mathrm{~kg} \mathrm{ha}^{-1[3]} \cdot \mathrm{P}_{2} \mathrm{O}_{5}$ and $\mathrm{K}_{2} \mathrm{O}$ used per ha increased from 14.0 to $31.0 \mathrm{~kg} \mathrm{ha}^{-1}$ and from 3.1 to $17.0 \mathrm{~kg} \mathrm{ha}^{-1}$ respectively, where the respective recommended doses are 40 and $20 \mathrm{~kg} \mathrm{ha}^{-1[3]}$.

From Table 5, it is found that the fertilizer energy input per ha increased 1.53-fold in 1985-90 and 1.34fold in 1990-95, where, it was 1.21-fold in 1980-85 and 1.1-fold in 1995-00. On the other hand, output energy per ha increased 1.25-fold in 1985-90 and 1.10-fold in $1990-95$ where, it was 1.05 -fold in $1980-85$ and 1.23 fold in 1995-00. The result shows that in 1985-90, fertilizer-input energy increased at highest level 1.79fold and output energy also increased at highest level 1.25-fold. Where in 1995-00, input increased at lowest level 1.04-fold, but output increased at next highest level 1.23-fold. Table 5 also shows that the energy input for irrigation increased linearly from $0.31 \mathrm{GJ} \mathrm{ha}^{-1}$ in 1980-81 to $0.62 \mathrm{GJ} \mathrm{ha}^{-1}$ in 2000-01. At the end of the study period, incremental fertilizer energy input is less sensitive to produce incremental energy output.

The relation between energy input/ha to energy output/ha is represented by an equation of $2^{\text {nd }}$ degree polynomial with a correlation coefficient $R^{2}=0.97$ and is shown in Fig. 1. Figure 2 represents the relation between energetic efficiency to energy input/ha through an equation of $2^{\text {nd }}$ degree polynomial with a correlation coefficient $R^{2}=0.98$. The Figure stated that the energetic efficiency declined with increasing energy input/ha and also the result indicates that input energy has increased faster compare to energy output. 


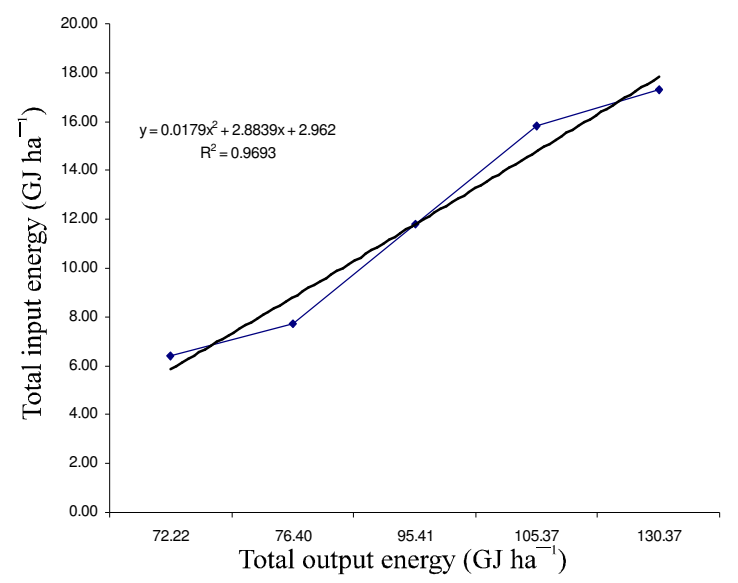

Fig. 1: Relation between total energy output $\left(\mathrm{GJ} \mathrm{ha}^{-1}\right)$ and total input energy (GJ ha ${ }^{-1}$ ) in 1980-812000-01

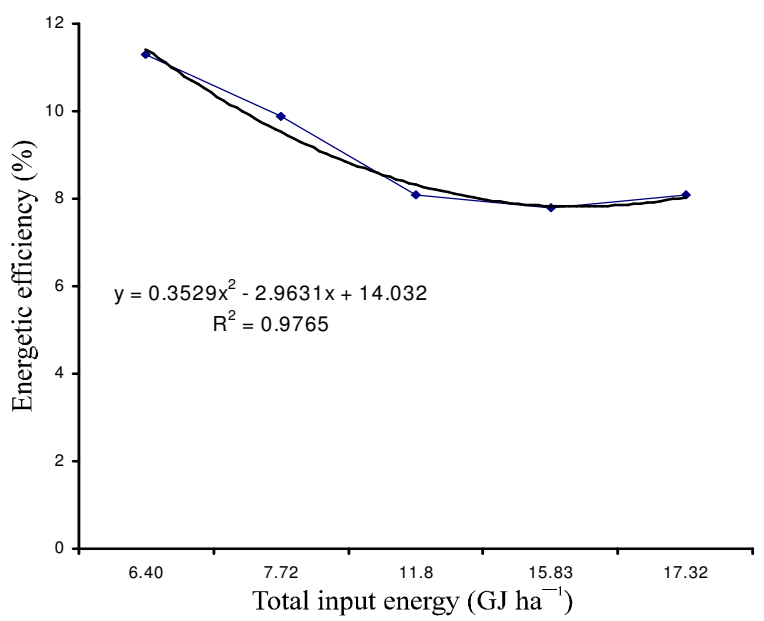

Fig. 2: Relation between total energy input $\left(\mathrm{GJ} \mathrm{ha}^{-1}\right)$ and energetic efficiency (\%) in 1980-812000-01

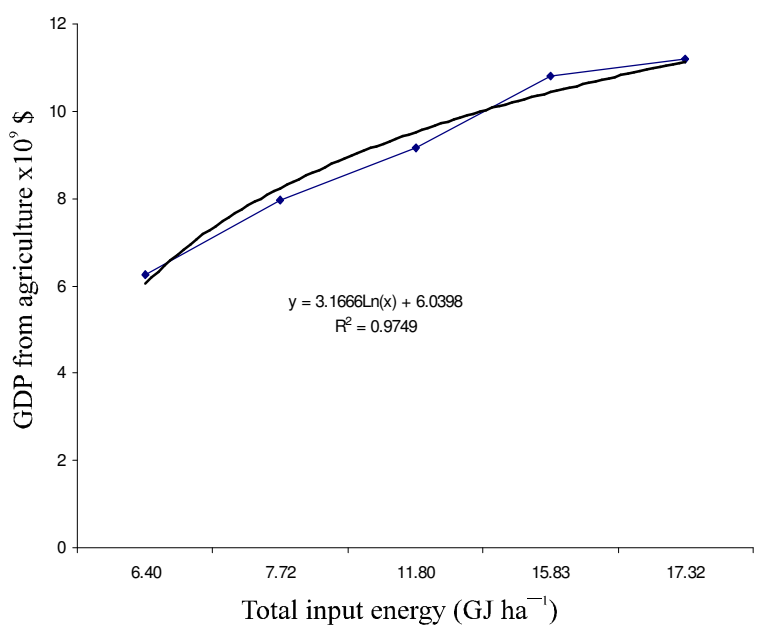

Fig. 3: Relation between total energy input (GJ ha $\left.{ }^{-1}\right)$ and GDP from agriculture $\times 10^{6} \$$ in $1980-81$ 2000-01

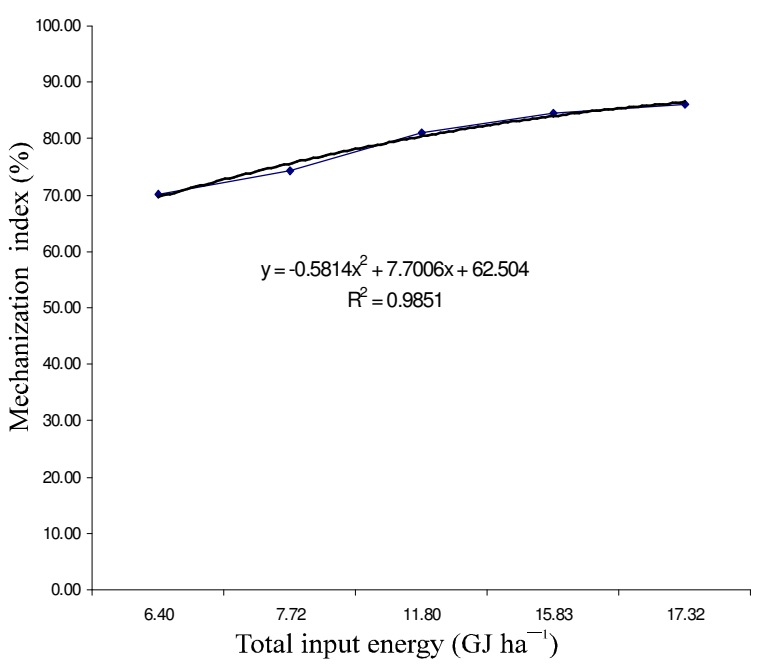

Fig. 4: Relation between total energy input (GJ ha $\left.{ }^{-1}\right)$ and Mechanization index (\%) in 1980-812000-01

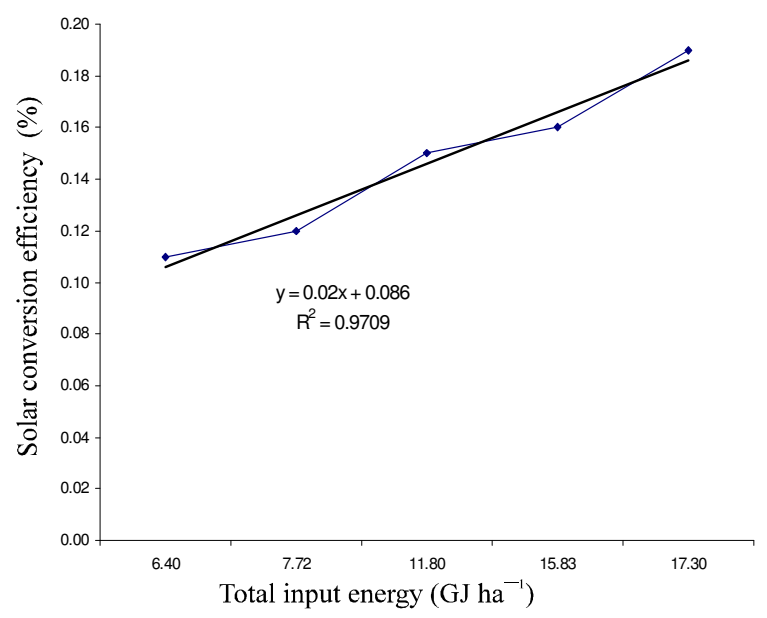

Fig. 5: Relation between total energy input (GJ ha ${ }^{-1}$ ) and solar conversion efficiency (\%) in 198080-2000-01

Figure 3 presents the GDP earned from agriculture with increasing energy input/ha through an equation of $2^{\text {nd }}$ degree polynomial with a correlation coefficient $\mathrm{R}^{2}=0.97$.

Table 5 shows that the energy input/ha increased from $86.4 \mathrm{MJ}$ in $1980-81$ to $123.5 \mathrm{MJ}$ in $2000-01$ to produce per unit GJ output and the energy input has increased from $0.89 \mathrm{MJ}$ in $1980-81$ to $1.41 \mathrm{MJ}$ in $2000-$ 01 to generate per million GDP. The result indicates for both the cases that input energy has gradually increased to produce per unit output either in the form of energy or in the form of GDP. Bangladeshi agricultural system has made a significant contribution to achieve self-sufficiency in food, fodder and cooking fuel. The indices show that the food, fodder and fuel production improved significantly in 2000-01 shown in Fig. 4. 
Figure 5 shows that the mechanization index has a tendency to reach the saturation level and solar conversion efficiency also increased linearly with the increasing of energy input/ha with a correlation coefficient $\mathrm{R}^{2}=0.97$ (Fig. 5). So, an enough scope is still open to achieve much more solar conversion efficiency through photosynthesis. At present, the conversion efficiency is being achieved at $0.21 \%$ in Bangladeshi agriculture, where the achievable conversion efficiency is $1.0-\%{ }^{[21]}$.

\section{CONCLUSION}

The role of energy input in Bangladeshi agriculture has been studied here in a quantitative basis based on some energy dependent indicators. The indicators are: energetic efficiency, mechanization index, food, fodder and fuel surplus indices, energy input to produce per unit energy output, energy input to generate per unit GDP output and solar conversion efficiency.

During the last 20 years, physical energy input, chemical energy input and seed energy input increased as $2.11,3.65$ and 1.71 fold respectively. Although it has been realized as 1.7-fold for energy yield. From 1980 to1995, the energetic efficiency declined linearly with the increase of input energy. The result indicates that inputs increases at faster rate compare to outputs. But in 2000-01, the increasing outputs are faster compare to its increasing inputs.

From above discussions, it has been realized that the draft power shortage has been overcome by providing the mechanical power input at the end of the last decade. Due to frequent floods and other natural disasters, draft power decreased from $0.25 \mathrm{~kW} \mathrm{ha}^{-1}$ in 1981 to $0.22 \mathrm{~kW} \mathrm{ha}{ }^{-1}$ in 2001 on the other hand machinery power for tillage was increased from 0.026 $\mathrm{kW} \mathrm{ha}{ }^{-1}$ in $1980-81$ to $0.276 \mathrm{~kW} \mathrm{ha}^{-1}$ in 2000-01 (Table 5).

Farmers are now habituating with modern agricultural technology. Fertilizer and pesticide are frequently used. Tillage operation is being rapidly mechanized. Irrigation is now completely mechanized. Irrigated area is also being increased fast. In this context, the overall mechanization of Bangladeshi agriculture has been evaluated based on mechanization index. The mechanization index was found $70 \%$ in $1980-81$ and $86 \%$ in $2000-01$ and its growth rate has a tendency to increase slowly.

Fertilizer use was found irrational. Recommended doses for fertilizers were not maintained. It was found used on over dose. It was also found that the output was less sensitive with the variation of fertilizer energy input at the end of the study period. Under such condition, soil fertility is now in great challenge.

The above results show that the energy output increased and GDP generated with increasing energy input.
But energy input gradually increased to produce either per unit energy output or per unit GDP output. Although the solar conversion efficiency increased linearly with increasing energy input. The result indicates that output doesn't properly follow the input. It implies that producers under take no more efficient production practice through proper energy input management. As a result, inputs increased faster compare to outputs.

Since there was a strong correlation between energy input and output as well as solar conversion efficiency, still there is an scope of increasing overall production by increasing solar conversion efficiency of the agricultural system and/or even by increasing energy input to agriculture. Which can help to solve the food, fodder and rural domestic cooking fuel problem. Moreover, the condition of agricultural mechanization is such that there is a scope to obtained the proportionality higher output-input energy ratio with increasing energy input and/or with increasing solar conversion efficiency. Though, the situation will be available up to a certain level of combination(s) of energy inputs, which level of combination(s) shall be determined.

Therefore, it may be concluded that energy inputs in Bangladeshi agriculture is still increasing and energy-related problems associated with agricultural production are still occurring. For this reason, it is necessary to promote development of new technologies to increase solar conversion efficiency and use of alternative input energy sources. It is suggested that specific policy(s) is to be taken to reduce the negative effect of energy inputs, such as pollution, global warning and nutrient loading. Within this framework energy flow analysis is an important task that will lead to develop more efficient, economic and environmentfriendly agricultural production system in Bangladesh.

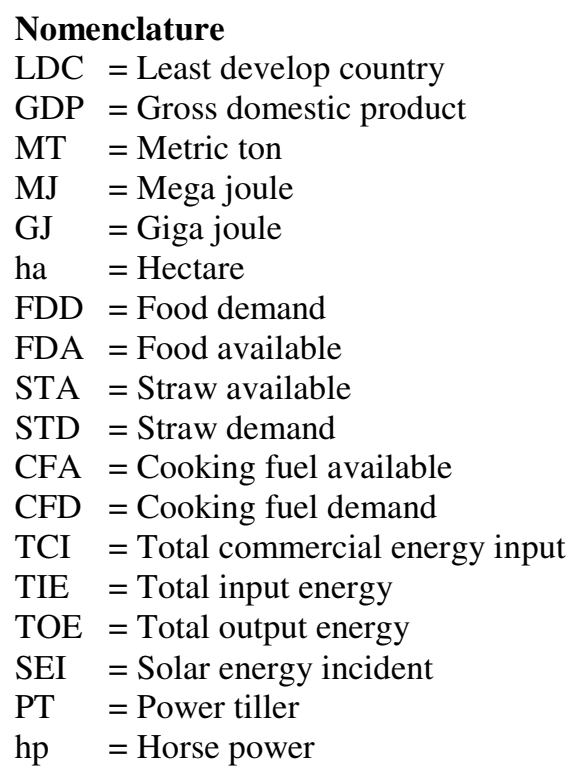




\section{REFERENCES}

1. Ozkan, B., H. Akcaoz and C. Fert, 2004. Energy input-output analysis in Turkish agriculture. Renewable Energy, 29: 39-51.

2. Government of Bangladesh, 2000. Statistical Yearbook of Bangladesh. 21st Edn. Dhaka: Bangladesh Bureau of Statistics.

3. Government of Bangladesh, 2002. Market monitoring information system (MMIS), Ministry of Agriculture, Govt. of Bangladesh. 2002. http://www.fadinap.org/ Bangladesh/ documents/ Statistics/tableC1.htm.

4. Government of Bangladesh, 2001. Sustainable Development Networking Program (SDNP), Agricultural database, Dhaka, Bangladesh. http://www.sdnbd.org/sdi/issues/agriculture/index. htm.

5. Food and Agricultural Organization (FAO), 2004. FAO statistical database: Agriculture, 1980 -2002. FAO: United Nations. http://fao.org/faostat/collections?version=ext\&hasb ulk=0\&subset=agriculture

6. Singh, R.B., 2002. The state of food and agriculture in Asia and Pacific. First version published by IFA and FAO, Parries, France, April 2002. $\quad$ pp 1-21. www.agroindonesia.com/Publications/2002_Singh. pdf.

7. Okurut, S. and W.R. Odogola, 1999. Farm power development in Uganda: Past, present and future trends. Proc.99 Intl. Conf. Agril. Engg., Beijing, China, 1: 232.

8. Warkentin, B.P., 1991. Protection of groundwater quality through efficient irrigation. Proc. Intl. Seminar on Efficient Water Use in Mexico City, Oct. 21-25, pp: 1.

9. Barton, D., 1999. Options for power tillers and draught animals on small farms. Proc. Workshop on Options for Farm Power Use in Primary Cultivation on Small Farms, Vol. 2. Mymensingh: Bangladesh Agricultural University.

10. Sarker, R.I., 1999. Farm power issues in Bangladesh: Options for primary cultivation on small farms. Proc. Workshop on Options for Farm Power Use in Primary Cultivation on Small Farms, Vol. 2 under the NRI Research Project A0784(X0395) Mymensingh: Bangladesh Agricultural University.
11. Borlaug, N.E. and C.R. Dowswell, 1993. To nourish infertile soil that feed a fertile population that crowds a fragile world. Fertilizer News, 38: 11-20.

12. Alam, M.S., A. Roychowdhury, A.K.M. Waliuzzaman and A.M.Z. Huq, 1999. Energy flow in family farming system of traditional village in Bangladesh. Energy-The Intl. J., 24: 537-545.

13 Alam, M.R., 2005. Computer simulation of input energy structure of Bangladesh agriculture. M. Sc Thesis. Dept. Electrical and Electronic, Chittagong University of Engineering and Technology, Chittagong, pp: VI.

14. Stout, B.A., 1990. Handbook of Energy Use for World Agriculture. Elsevior Pub., pp: 120.

15. Salokhe, V.M. and N. Ramalingam, 1998. Agricultural Mechanization in the South and south east Asia. Proc. Intl. Conf. Soc. Agril. Engineers, Las Banos, Philippine, April 21-24, pp: 6-9. http://hcgl.org.ohiostate.edu/ nagaraja/Mechanization.pdf.

16. Shrestha, D.S., 1998. Energy input and output and their cost analysis in Nepalese agriculture. http:/www.publiciastate.edu/ dev/pdfdocs/Energy. PDF.

17. Alam, M.S., 1991. Integrated modeling of rural energy system: A system dynamics approach. Ph.D Thesis. Department of Electric and Electronic Engineering, Bangladesh University of Engineering and Technology, Dhaka, pp: 250-260.

18. Stout, B.A. and C.A. Meyer, 1978. AMA 9, 11 USA.

19. Bala, B.K., 1998. Energy and Environment: Modeling and Simulation. New York, Nova Science Publisher, Inc., pp: 184.

20. Satter, M.A., 1995. A system dynamics model to assess the impacts of agricultural mechanization on rice production in Bangladesh. $\mathrm{Ph}$. D Thesis. Mymensingh: Bangladesh Agricultural University.

21. Alam, M.S., S.C. Biswas and M.M. Pal, 1993. Dynamic model for the assessment of input energy structure of agriculture sector in Bangladesh. Paper Presented at the 37th Ann. Conv. Institution of Engineers of Bangladesh, Dhaka, pp: 1-5. 